\title{
Staff and Students Views on Industry-University Collaboration in Engineering
}

\author{
http://dx.doi.org/10.3991/ijac.v8i2.4408 \\ Sivachandran Chandrasekaran, Guy Littlefair, Alex Stojcevski \\ Deakin University, Geelong, Australia
}

\begin{abstract}
The university-learning environment in engineering is not sufficient for students to become engineers. The practical role of engineering is working on real world problems in an industry environment. Industry-university collaboration seems to be actively increasing in the development of engineering education in various parts of the globe. The close relationship between industry and university is a vital component of engineering pedagogy in Australia. This research paper is focuses on analyzing staff and students views on industry-university collaboration in engineering. The staff and students are playing vital role in industryuniversity collaboration. It is always worth analyzing staff and students' views about their experience on industryuniversity collaboration. This research inclined to conduct a paper based survey with a cohort of students in second year undergraduate engineering course and also conduct face-toface interview with staff members in the School of Engineering at Deakin University.
\end{abstract}

Index Terms-Students' views, staff views, industryuniversity collaboration.

\section{INTRODUCTION}

The real value of industry collaboration is to create benefits for society. Universities focus on educating students as professionals while industry concentrates on giving opportunities to students to experience real world problems in a competitive environment. The core interest is different for both industry and university. Academics pursue the practice of teaching theory to practice through research projects within an engineering curriculum. The industry expects graduates with career ready skills such, as problem solving, analytical thinking, and design to work on real world projects. The industry expects creative and innovative academic practice that gives students valuable practical knowledge.

It's a drawback for students and young professionals in engineering who don't have any knowledge of real world problems, and it becomes a challenging task for any graduate to face their future career without a link to industry. The aim of all engineering degrees is to provide a strong grounding with principles of engineering science and technology. By determining the engineering methods and approaches in an academic environment, graduates unable to go into the world of work and tackle real world problems with innovation and creativity have difficulty.

This research paper is focused on analyzing staff and students' views on industry-university collaboration. The students and staff are playing vital role in industryuniversity collaboration. It is always worth analyzing staff and students' views about their experience on industryuniversity collaboration. This research inclined to conduct a paper based survey with a cohort of students in second year undergraduate engineering course and also conduct face-to-face interview with staff members in the School of Engineering at Deakin University.

\section{Challenges AND OpPURTUNITIES}

\section{A. Challenges in industry-university collaboration}

With close industry and university relationships; academics are more concerned about undesirable consequences to university life, such as loss of academic freedom, long-term research, and academic integrity. Industry is facing two fundamental issues that affect collaboration. First, the open nature of engineering science within the academy is at times in conflict with companies. Second, academic research focuses on long-term challenges, which take more time to complete. Research and development in industry are driven by time-sensitive product development projects and day-to-day problem solving drive research and development in industry.

In research and development based projects, student work experience and staff training are becoming the most frequent domains for university-industry collaboration. However, some industry enterprises are perhaps considered to be the most critical external factors, which affect the university's progress to produce student knowledge [1]. Author Kurtulus Kaymaz mentioned the barriers of university and industry collaboration from an academician's perspective. These barriers include lack of interest from both sides, management issues, lack of communication, ineffective legal regulations, ineffective universityindustry collaboration centers and previous bad experiences. There is always room for cultural reform between university and industry relations. These cultural differences must not be considered as barriers for universityindustry collaboration [2-4].

\section{B. Oppurtunities in industry-university collaboration}

University and industry collaboration will benefit the university in many ways. It provides training and employment opportunities for students to explore the visible impact of engineering on the local, regional and state economic problems [2]. Universities, moreover, have an important benefit of understanding the future needs of society regarding new products, processes, and services. In long-term university collaboration, industry will benefit with a possible higher recruitment rate of graduates every year, which fosters their brand name in the education marketplace. Students gain the chance to understand current challenges, career insights, and job training in industry. 
Industry and university collaboration is driving and facilitating the innovative process in technologies with the interaction between the creators and users of knowledge. Research and Development (R\&D) is a key process that enriches close relationships between industry and university. Industry helps academics change or update their methods of learning and teaching. Industry works together with educational institutions for renewal and redirection of engineering education $[5,6]$.

Universities provide basic research that is considered expensive for industry. It is time consuming and cost effective for industry to collaborate with university-based research. Even students get a chance to undertake an industry-based project that creates future career opportunities. Through industry and university collaboration, students can improve their knowledge of technology development and industry practices. Dr Andy K H SEO, Vice President of the Federation of Malaysian manufacturers mentioned industry and university collaboration.

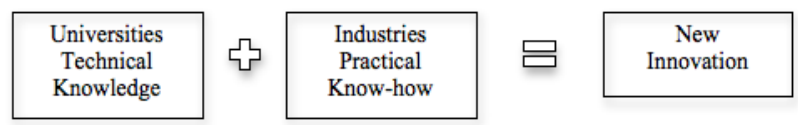

Figure 1. Win-Win relationship [2]

It is possible that academics might misunderstand or possibly overstate industry intentions which are clearly stated in a study of literature [2]. We need to clarify the industry expectations, requirements and conditions for academics in university collaboration.

\section{RESEARCH METHOdOLOGY}

\section{A. Paper based survey for students}

The paper-based survey was conducted on the cohort of students in second year undergraduate engineering course. The survey questions were based on quantitative and qualitative analysis. In line with the ethics approval process and procedures, a third party carried out the paper based research survey. The data collected was anonymous and unidentified. The collected data was analysed to derive a quantitative outcome, which shows the students' perception on industry-university collaboration. The survey questions were proposed to analyse students experience and expectations on industry collaboration. The paper based survey questions were:

- What is meant by industry-university collaboration?

- List different ways to approach industry collaboration with an Engineering curriculum?

- At which level do you recommend a curriculum involve small or large industry based projects?

- How important is industry collaboration to your future career?

- How important is industry collaboration to your final year project?

- What is your assumption on graduate attributes, learning outcomes and industry based activities?

- To what extent do you feel industry collaboration will improve the graduates' ability to gain employment?

\section{B. Face to face interview with staff}

The face-to-face interviews were scheduled via e-mail or phone calls to indicate staff availability. Only the re- search assistant involved in this research project conducted the interviews. The plain language statement and consent form was attached with the initial e-mail sent to participants. The consent form was collected at the end of the interview. The call to participant was voluntary and did not infringe with any privacy requirements.

In line with the ethics approval process and procedures, the research assistant sent individual E-mails to every staff member in the School of Engineering. When a staff given an appointment time, the research assistant will conducted the face-to-face interview. An interview question set was asked to each staff that teaches and performs research in engineering design. The data collected was anonymous and non-identifiable. The collected data was analysed to derive a quantitative outcome that shows the staff perceptions on industry-university collaboration.

The data was collected through audio recordings during face-to-face interviews and it was fully non- identifiable and anonymous. No personal details were taken from the participants. Written consent forms from the participants will be maintained separately from the electronic data that is non-identifiable. Around 18 staff members who teach and perform research in engineering design at the School of engineering at Deakin University participated on faceto-face interviews. The inclusion criteria included staff members working in all engineering disciplines.

\section{RESUlts}

\section{A. Students views}

Students and staff play a vital role in industryuniversity collaboration. It is always worth analyzing students' perspectives about their experience on industryuniversity collaboration. This research inclined to conduct a paper based survey with a cohort of students in second year undergraduate engineering course. Table I illustrates students' views on academic-industry partnerships. It was interesting to see that most of the students (34\%) realized an industry-university collaboration is a supportive cooperation from both sides, which is a WIN - WIN situation. About $22 \%$ mentioned that an academic-industry partnership means sharing resources and funds to achieve a goal that benefits both sides.

Table II explains students' views on different ways to approach industry collaboration with engineering curriculum. Students $(49 \%)$ believed that industry-university collaboration be approached through research projects (through industry sponsored projects), apprentice training and knowledge exchange events such as inviting industry representatives for guest lectures and organizing poster exhibitions.

TABLE I.

INDUSTRY-UNIVERSITY COLLABORATION

\begin{tabular}{|l|l|}
\hline \multicolumn{1}{|c|}{ Students perceptions } & $\%$ \\
\hline Academic and industry partnership & 11 \\
\hline Industry funding for university research activities & 11 \\
\hline Technology/knowledge sharing by university and industry & 22 \\
\hline Supportive cooperation from both sides Win-Win situation & 34 \\
\hline $\begin{array}{l}\text { Sharing research resources and funds to achieve a goal that } \\
\text { benefits both sides }\end{array}$ & 22 \\
\hline
\end{tabular}


TABLE II.

DIFFERENT WAYS TO APPROACH INDUSTRY COLLABORATION WITH ENGINEERING CURRICULUM

\begin{tabular}{|l|l|}
\hline \multicolumn{1}{|c|}{ Students perceptions } & $\%$ \\
\hline $\begin{array}{l}\text { Research projects, apprentice training and knowledge } \\
\text { exchange events }\end{array}$ & 49 \\
\hline Vacation employment and placements & 16 \\
\hline Mutual understanding, industrial visit for students & 11 \\
\hline Internship programs in engineering & 12 \\
\hline Small research training that benefit students & 12 \\
\hline
\end{tabular}

Figure 2 shows students' views on recommending a curriculum to involve industry-based projects. About $44 \%$ students suggest to have industry based projects in year 3 , $34 \%$ want projects in year 4 and $22 \%$ students expect industry projects in the year 2. John Webster [7] recommends that engineering courses must be outcome-oriented and equip graduates for lifelong learning. In addition, he also suggests that in an engineering first year, most of the time should spend on mathematical and scientific fundamentals that underpin all engineering disciplines. If the curriculum is based around projects, the actual projects should be defined and structured by teachers in the first year for students to obtain the fundamental knowledge. In the second and third year, students work in industry and/or community projects, and industry practice takes place in the final year [7]

The cohort of students of $55 \%$ and $44 \%$ says industry collaboration is necessary and does help with their future career (figure 3). Overall $100 \%$ of students revealed that industry collaboration is necessary and does help their final year project (figure 4). Figure 5 shows students views on industry collaboration. Approximately $100 \%$ of students mention that industry collaboration helps to improve the graduates' ability to gain employment.

It is interesting to look at figure 6 illustrates the student assumption on graduate attributes, learning outcomes and industry based activities. Students were given the option to rate their assumption from 1 to 5 (low to high level). Nearly $44 \%$ of students rated the curriculum content as rating 4 (high level) and industry based activities as rating 5 (very high level). Only 22\% - 33\% rated student initiative from $3-4$ (Medium to High level). Overall, student views were expected to show more interest in curriculum content and industry based activities than their own initiatives. These survey results show students' involvement and expectations of industry-university collaboration.

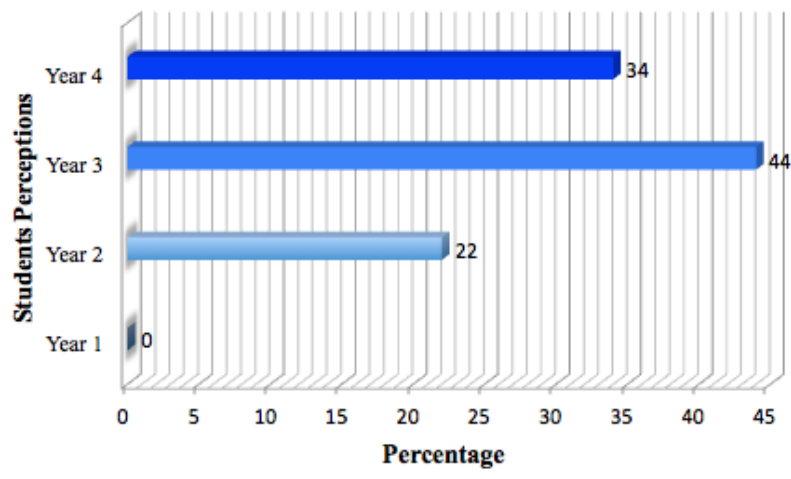

Figure 2. Students recommending a curriculum to involve industry based projects

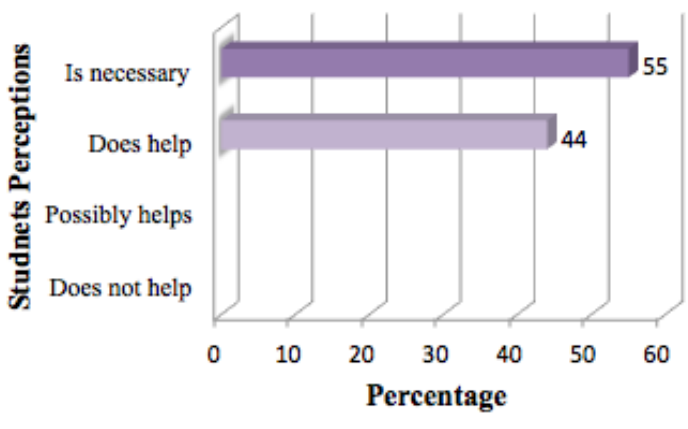

Figure 3. Industry collaboration to future career

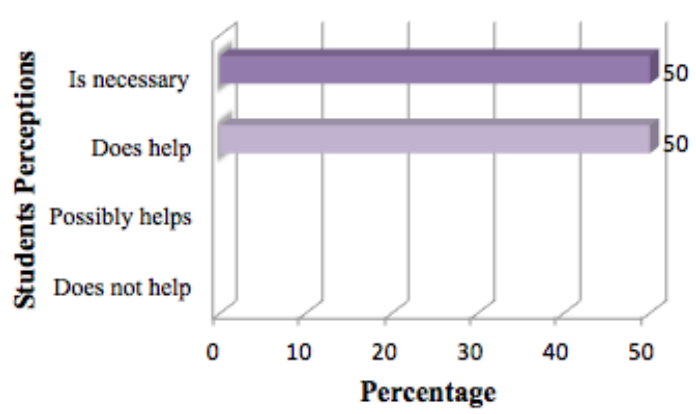

Figure 4. Industry collaboration to final year project

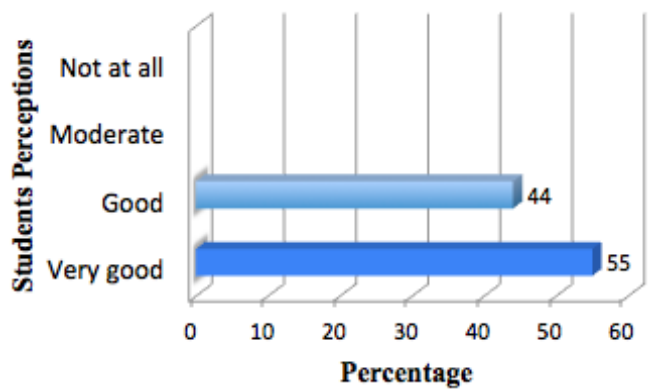

Figure 5. Industry collaboration improves the graduates' ability to gain employment

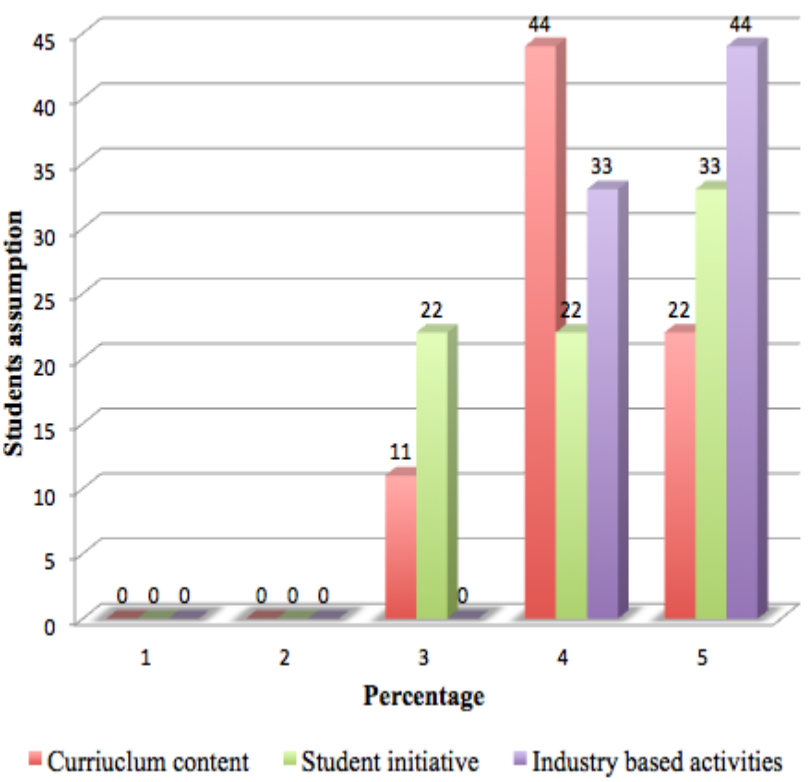

Figure 6. Student assumption on graduate attributes, learning outcomes and industry-based activities 


\section{B. Staff views}

The staff members in the School of Engineering at Deakin University also illustrated their views on industry and university collaboration. Staff views were about understanding what the industry needs and strength of academics in industry collaboration were, identifying what the industry problems are, and what their capabilities are to solve these issues. Staff views were collected through face-to-face interviews, and collected data was presented in quantitative form. Table III illustrates staff views on how university collaborates with industry. Overall staff members expect industry and university to work together in research areas. As the university is a provider of engineering graduates to industry, there must be strong collaboration.

Table IV shows staff perceptions on curriculum involvement in industry-based projects. Roughly $92 \%$ of staff members say their curriculum involves industrybased projects through final year projects, industry placements in 2nd and 3rd year and through unit content (program structure). Only $8 \%$ say there is not much involvement of industry-based projects in their curriculum.

Staff members who practice design projects at Deakin University state their views on the impact of industry and university collaboration in Table V. Most of the staff members say industry and university collaboration is beneficial by implementing more industry relevant curriculum, which helps the students for their future career opportunities through short term and long-term industry based projects.

Table VI shows staff views on barriers to industryuniversity collaboration. Staff revealed that research priorities differ between university and industry, such as timing, short term or long-term research interest, lack of frequent communication, and investing funds for research. There is not enough space for student welfare or academic development in industry and university collaboration. Table VII illustrates staff perceptions on an academic curriculum displaying the expectations of industry requirements. More than $50 \%$ of staff expects the academic curriculum to have a flexible university system, which helps to maximize industry collaboration.

Table VIII explains staff views on their goals to drive the collaboration of industry and university. Table IX lists some staff teaching activities that help their curriculum include industry partnerships. A larger number of staff mentioned their teaching activities such as problem solving through final year projects and design projects by active learning.

TABLE III

UNIVERSITY COLLABORATION WITH INDUSTRY

\begin{tabular}{|l|c|}
\hline \multicolumn{1}{|c|}{ Staff perspectives } & $\mathbf{\%}$ \\
\hline By attending relevant open meetings or workshop & 21 \\
\hline $\begin{array}{l}\text { Final year projects, industry placements, industry advisory } \\
\text { boards }\end{array}$ & 21 \\
\hline $\begin{array}{l}\text { Through suppliers such as tooling companies satisfying re- } \\
\text { search end users }\end{array}$ & 18 \\
\hline Project collaboration, research or consulting & 21 \\
\hline $\begin{array}{l}\text { Curriculum industry readiness, several ways such as straight } \\
\text { contract research, potential for more scientific problems (future } \\
\text { needs) blue sky project, Engineering lecture (top researcher) }\end{array}$ & 18 \\
\hline
\end{tabular}

TABLE IV

CURRICULUM INVOLVING INDUSTRY-BASED PROJECTS

\begin{tabular}{|l|c|}
\hline \multicolumn{1}{|c|}{ Staff perspectives } & $\%$ \\
\hline $\begin{array}{l}\text { Yes, through the final year project, } 2^{\text {nd }} / 3^{\text {rd }} \\
\text { placements (scholarships for students) }\end{array}$ & 92 \\
\hline No & 8 \\
\hline
\end{tabular}

TABLE V.

IMPACTS OF INDUSTRY-UNIVERSITY COLLABORATION

\begin{tabular}{|l|c|}
\hline \multicolumn{1}{|c|}{ Staff perspectives } & $\mathbf{0}$ \\
\hline Research objectives will be more user friendly (Huge impacts) & 14 \\
\hline $\begin{array}{l}\text { Implementing more industry relevant curriculum, employable } \\
\text { graduates, beneficial to students }\end{array}$ & 35 \\
\hline $\begin{array}{l}\text { Beneficial to overall development of science, industry and } \\
\text { university, stakeholders in research }\end{array}$ & 15 \\
\hline $\begin{array}{l}\text { Benefit through small problems (industry), good for reputation, } \\
\text { real world problems relevant to industry (university) }\end{array}$ & 14 \\
\hline $\begin{array}{l}\text { Learn more about the real application (university), solve prob- } \\
\text { lems wisely (industry), industry focus on specific problem }\end{array}$ & 22 \\
\hline
\end{tabular}

TABLE VI

BARRIERS TO INDUSTRY-UNIVERSITY COLLABORATION

\begin{tabular}{|l|c|}
\hline \multicolumn{1}{|c|}{ Staff perspectives } & $\mathbf{\%}$ \\
\hline Industry focus on products but academic focus on research & 28 \\
\hline $\begin{array}{l}\text { Staff publish or perish, forced to focus on research, intellectual } \\
\text { property issues, reluctance by staff }\end{array}$ & 14 \\
\hline $\begin{array}{l}\text { Lack of experience of staff in the industry, lack of contact } \\
\text { communication) }\end{array}$ & 30 \\
\hline $\begin{array}{l}\text { Timely availability of staff, dependent people, commitment of } \\
\text { staff member, encouragement from management }\end{array}$ & 14 \\
\hline $\begin{array}{l}\text { Time issue, no funding, no interest, hard to fulfill the industry } \\
\text { requirement }\end{array}$ & 14 \\
\hline
\end{tabular}

TABLE VII.

ACADEMIC CURRICULUM DISPLAYING INDUSTRY REQUIREMENT

\begin{tabular}{|l|c|}
\hline \multicolumn{1}{|c|}{ Staff perspectives } & $\%$ \\
\hline $60 \%$ & 28 \\
\hline $30 \%$ & 14 \\
\hline Flexibility in university system & 44 \\
\hline Should be maximized, align with industry & 14 \\
\hline
\end{tabular}

TABLE VIII.

GOALS TO DRIVE INDUSTRY-UNIVERSITY COLLABORATION

\begin{tabular}{|l|c|}
\hline \multicolumn{1}{|c|}{ Staff perspectives } & \% \\
\hline $\begin{array}{l}\text { Through research collaboration, by partnership, patent and } \\
\text { grants }\end{array}$ & 28 \\
\hline $\begin{array}{l}\text { To base our research on real time industrial environment. Be an } \\
\text { efficient provider of solutions for growth of the industry and } \\
\text { university }\end{array}$ & 8 \\
\hline $\begin{array}{l}\text { Correct balance of knowledge, skills, program relevant to } \\
\text { industry requirement }\end{array}$ & 28 \\
\hline $\begin{array}{l}\text { Make easier for the industry, enhance certain academic profes- } \\
\text { sional skills, make students ready for jobs }\end{array}$ & 21 \\
\hline $\begin{array}{l}\text { Blue sky + big package projects, undergraduate training, final } \\
\text { year projects, acknowledgement of expectations, courses with } \\
\text { sufficient practical experience }\end{array}$ & 15 \\
\hline
\end{tabular}

TABLE IX

TEACHING ACTIVITIES THAT HELP CURRICULUM TO INCLUDE INDUSTRY PARTNERSHIP

\begin{tabular}{|l|c|}
\hline \multicolumn{1}{|c|}{ Staff perspectives } & $\mathbf{\%}$ \\
\hline Inviting external speakers & 14 \\
\hline Workshops, Industry partner mentoring & 8 \\
\hline Guest lectures, focus identity groups & 14 \\
\hline $\begin{array}{l}\text { Making students adapt to practical based teaching such as in } \\
\text { manufacturing }\end{array}$ & 8 \\
\hline $\begin{array}{l}\text { Problem solving relevant to industry, final year projects, } \\
\text { industry placements, design projects }\end{array}$ & 42 \\
\hline $\begin{array}{l}\text { Active learning, group design work, industry based projects } \\
(12 \text { weeks) }\end{array}$ & 14 \\
\hline
\end{tabular}


The overall staff perceptions explain their curiosity and flexibility in developing and improving industry collaboration. This is a positive sign for the School of Engineering at Deakin University to further develop industry partnerships. During the research process industry perspective on industry and university collaboration was also obtained. A paper-based survey was conducted with all industry representatives in an engineering industry advisory in the School of Engineering at Deakin University. Industry is always looking for revised skills from graduates to work on future customer needs in the industrial environment. Table $\mathrm{X}$ shows several attributes expected by the industry in recent graduates.

Industry expects graduates to be self-confident, ready to learn new things, to have good practical knowledge with management skills, communication with customers, analytical thinking and leadership skills. The overall industry perspectives are encouraging for academics. From these survey results, academics and industry are very clear they want to work together for enhanced collaboration.

\section{COLlaborative RESEARCH}

Industrial participation in learning and teaching provides further opportunities for students to acquire knowledge on specialist engineering topics, awareness about industrial and commercial realities, and development of vital transferable skills. When identifying graduate attributes, particularly for undergraduate engineering programs in Australia, the program accrediting body (EA) initiates a set of attribute elements mentioned in 'Stage1 Competencies and Elements of Competency'. It states that one of the important abilities is the application of systematic engineering synthesis and design processes. Industry and academic collaborative research is highly regarded by the professional accreditation bodies such as Engineers Australia (EA), Accreditation Board of Engineering and Technology (ABET) and, European Accreditation of Engineering Programs (EUR-ACE) [8-10].

A research study performed by the Australian Industry Group (AIG) shows that most employers reported difficulty in recruiting people with practical trade skills as well as generic skills. The inadequate skills of existing employees were also reported [11]. Australian industries are facing an increasingly tougher environment. Graduates need worldclass skills in order to survive and grow to compete with the current global manufacturing market. Universities need to deliver higher quality teaching and learning in engineering and technology. Collaborative research is a flexible approach that always opens new proposals and new partnerships.

This research study performed a paper-based survey to investigate industry and academic requirements for students focusing on achieving job ready skills through collaborative research. From the survey results, a collaborative research model for sustainable design for industry and academia is illustrated in figure 7.

University projects require students to undertake their own fact-finding and analysis, either from library/internet research or from gathering data empirically. Industry projects are project-based activities in partnership with an industry organisation. Students complete a research project focused on a given leisure, event or industry issue, problem or opportunity. Community projects provide a unique opportunity to extend student learning and broaden
TABLE X.

ATTRIBUTES LOOKED FOR IN RECENT GRADUATES

\begin{tabular}{|l|c|}
\hline \multicolumn{1}{|c|}{ Industry perspectives } & $\%$ \\
\hline $\begin{array}{l}\text { Communication skills - leadership skills/ Industry knowledge } \\
\text { / technical / analytical skills } \\
\text { Broad management skills }\end{array}$ & 28 \\
\hline $\begin{array}{l}\text { Intelligent, forward thinking, takes responsibilities for their } \\
\text { actions, willing to learn, has an understanding that engineering } \\
\text { is a career not a means to make money }\end{array}$ & 21 \\
\hline $\begin{array}{l}\text { Technical knowledge, good personality, i.e., able to communi- } \\
\text { cate at a reasonable level, have an open mind }\end{array}$ & 14 \\
\hline
\end{tabular}

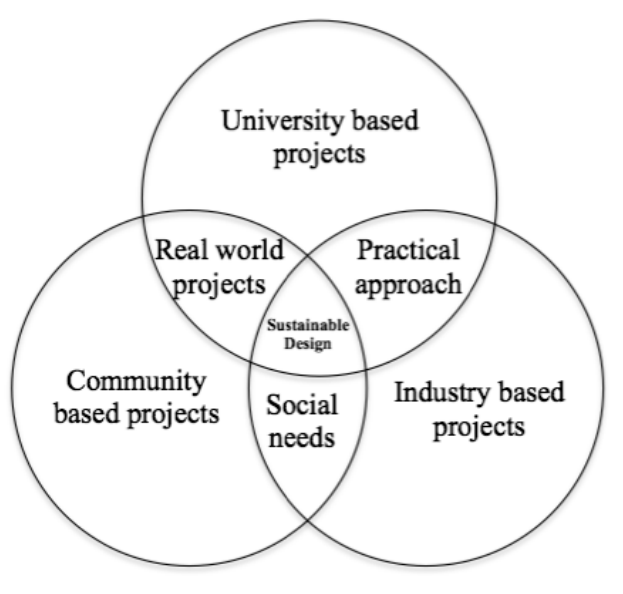

Figure 7. Collaborative research model

experiences beyond the academic environment. The collaborative research model benefits all the stakeholders such as students, industry, community, and of course the university[12-15]. It provides a framework for embedding experiential and rich learning activities, integrated with discipline-based curriculum that improves employment and career outcomes [16, 17].

\section{RECOMMENDATIONS}

The 2010 Australian survey of student engagement (AUSSE) reported that Deakin first year students who engaged in their learning obtained sound learning outcomes in a supportive learning environment. The study also shows that Deakin's later year students were well prepared to enter the workforce (career readiness) through work integrated learning [18]. At Deakin University, work integrated learning contributes to provide opportunities for students to effectively combine study, work and other interests by integrating opportunities for experiential learning into appropriate courses. Deakin University has used its strong linkages with business, industry and community organizations in enhancing work integrated learning placements for the students [19].

Work integrated learning provides students the opportunity to learn a variety of skills by expanding the walls of classroom learning to include the community [20]. By narrowing the gap between theory and practice, work integrated learning creates meaning for students. They provide opportunities for students to learn a variety of skills through in-depth academic preparation with handson project focused experiences. Under the guidance of facilitators, students learn to work in teams, solve problems, and meet employers' expectations. Through work integrated learning experiences students see how classroom instruction connects to the world of work and future career opportunities. Experiences include, but not limited 
to, apprenticeships, career fairs, field studies, guest speakers, job shadows, and student internships [20].

The collaboration of industry with university aims to approach practical knowledge applied with scientific knowledge created by academics to create innovative outcomes. It is necessary to establish a knowledge flow between industry and university that enhances collaborative knowledge on both sides. Table XI summarises the following key points for academics collaborating with industry and industry that seeks to collaborate with university staff members. Academia is a provider of graduates to industry. Universities have always enhanced partnership regulations to work with industry.

This research analysed the views of staff and industry representatives to propose an industry and academiatraining agenda, which is shown below in Figure 8. The agenda includes industry partners acting as mentors for academic staff members to clarify what industry problems exist and what is needed to resolve these issues. Projects can be developed to resolve these issues will occur through industry advisory group meetings, industry based workshops, design discussion forums and identity focus groups.

\section{CONCLUSION}

This research project analyses students and staff perceptions on academic-industry partnerships at Deakin University. The data was collected through paper-based surveys, face-to-face interviews, and focus groups. It remains a challenging task for academics and industry representatives to maintain active participation in industry-university collaboration. Academics and industry possibly maintain this sustained relationship by providing regular feedback, reviewing goals and objectives, improving communication, keeping focused and sharing the vision. It is clearly stated in this research that the students and staff obtained positive and encouraging views on industry-university collaboration. Students, staff realized the value of close collaboration between industry and university.

\section{REFERENCES}

[1] K. E. Kaymaz, Kadir Yasin, "Determining Factors Hindering University-Industry Collaboration: An Analysis from the Perspective of Academicians in the Context of Entrepreneurial Science Paradigm," International Journal of Social Inquiry, vol. 4, pp. 185-213, 2011.

[2] Y. S. Lee, "'Technology transfer' and the research university: a search for the boundaries of university-industry collaboration," Research Policy 25, vol. 25, pp. 843-863, 1996.

[3] J. B. Ammon Salter, Pablo D'Este, "Investigating the factors that diminish the barriers to university-industry collaboration," Research Policy vol. 39, p. 858, 2010. http://dx.doi.org/10.1016/j.respol.2010.03.006

[4] D. T. Koch, "Drivers and Challenges in University/Industry Collaborative research," in EUIMA Workshop, ed. Cambridge, 2011.

[5] K. Korhonen-Yrjänheikki, T. Tukiainen, and M. Takala, "New challenging approaches to engineering education: enhancing university-industry co-operation," European Journal of Engineering Education, vol. 32, pp. 167-179, 2007. http://dx.doi.org/10.1080/03043790601118697

[6] R. Welsh, L. Glenna, W. Lacy, and D. Biscotti, "Close enough but not too far: Assessing the effects of university-industry research relationships and the rise of academic capitalism," Research Policy, vol. 37, pp. 1854-1864, 12// 2008.

[7] J. A. Webster, "Engineering Education in Australia," Int. J. Engng Ed., vol. 16, pp. 146-153, 2000.
TABLE XI.

MOTIVATIONS FOR COLLABORATION

\begin{tabular}{|c|c|}
\hline \multicolumn{2}{|c|}{ Motivations for collaboration } \\
\hline Academics views & Industry views \\
\hline $\begin{array}{l}\text { a) To achieve knowledge devel- } \\
\text { opment about practical prob- } \\
\text { lems useful for curriculum en- } \\
\text { hancement. } \\
\text { b) To create internships and job } \\
\text { placement opportunities for } \\
\text { students. } \\
\text { c) To obtain insights in the area of } \\
\text { staff members own research. } \\
\text { d) To examine the practical appli- } \\
\text { cation of current research for } \\
\text { future needs. } \\
\text { e) To share government funding } \\
\text { on small and big research pro- } \\
\text { jects. }\end{array}$ & $\begin{array}{l}\text { f) To develop new product } \\
\text { and processes. } \\
\text { g) To improve product quality } \\
\text { by enhancing research and } \\
\text { development progress. } \\
\text { h) To maintain an ongoing } \\
\text { relationship with the uni- } \\
\text { versity. } \\
\text { i) To conduct blue-sky re- } \\
\text { search and to recruit gradu- } \\
\text { ates. } \\
\text { j) To conduct fundamental } \\
\text { research with open research } \\
\text { ideas. }\end{array}$ \\
\hline
\end{tabular}

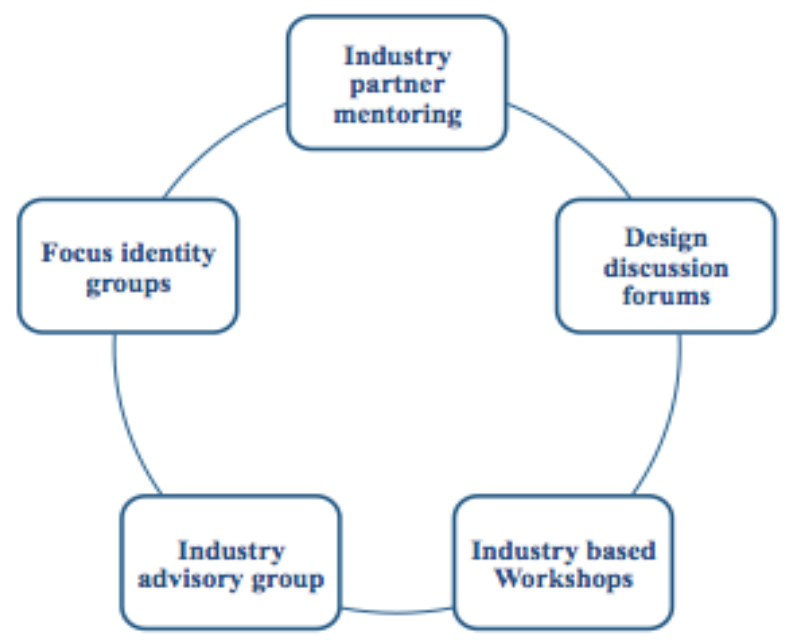

Figure 8. Collaborative training agenda

[8] ABET, "Criteria for accrediting engineering programs " in effective for evaluations during the 2012-2013 accreditation cycle, ed: Accreditation Borad of Engineering and Technology, 20122013.

[9] ENAEE, "EUR-ACE Framework standards for the accreditation of engineering programmes ", ed: European Network for Accreditation of Engineering Education, 2008.

[10] EA, "Stage1 competency standard for professional engineer," ed. Australia: Engineers Australia, 2012.

[11] S. K, "world class skills for world class industries: Employers' perspectives on skilling in Autralia," Australian Industry Group, sydney 2006.

[12] S. Chandrasekaran, A. Stojcevski, G. Littlefair, and M. Joordens, "Project-oriented design-based learning: aligning students' views with industry needs," International journal of engineering education, vol. 29, pp. 1109-1118, 2013.

[13] S. Chandrasekaran, A. Stojcevski, G. Littlefair, and M. Joordens, "Design Based Learning - Students Views on Industry Requirements," presented at the International Symposium on Project Approaches in Engineering Education(PAEE), Eindhoven University of Technology, the Netherlands, 2013.

[14] S. Chandrasekaran, A. M. Than Oo, A. Stojcevski, and G. Littlefair, "Best assessment practices of final year engineering projects in Australia," 2013, pp. 1-17.

[15] S. Chandrasekaran, A. Stojcevski, G. Littlefair, and M. Joordens, "Alinging Students and Staff Perspectives in Design Curriculum," in Proceedings of the Research in Engineering Education Symposium 2013, Kuala Lumpur, 2013.

[16] S. D. R. Bloedon R.V, "Making university/industry collaborative research suceed," Research Technology Management, vol. 37, 1994. 
[17] Y. Lee, "The Sustainability of University-Industry Research Collaboration: An Empirical Assessment," The Journal of Technology Transfer, vol. 25, pp. 111-133, 2000. http://dx.doi.org/10.1023/A:1007895322042

[18] AUSSE, "Australasian Survey of Student Engagement (AUSSE:) report on the results from the 2010 survey," 2010.

[19] A. G. TEQSA, "Report of an Audit of Deakin University," 2012.

[20] D. Malicky, Huang, M., Lord, S.,, "Problem, Project, Inquiry, or Subject-Based Pedagogies: What to do?," American Society for Engineering Education, 2006.

\section{AUTHORS}

Sivachandran Chandrasekaran is with the School of Engineering, Deakin University, Geelong, Australia (siva.chandrasekaran@deakin.edu.au).

Guy Littlefair is with the School of Engineering, Deakin University, Geelong, Australia (guy.littlefair@deakin.edu.au).

Alex Stojcevski is with the School of Engineering, Deakin University, Geelong, Australia (alex.stojcevski@deakin.edu.au).

Submitted 03 February 2015. Published as resubmitted by the authors 02 June 2015. 